УДК $323+316.35$

https://doi.org/10.34142/24130060.2019.17.1.18

\title{
ГРОМАДСЬКІ ОБ’ЄДНАННЯ ЯК ЧИННИК ДЕРЖАВОТВОРЕННЯ: ВИЗНАЧЕННЯ ПРОБЛЕМНОГО ПОЛЯ ДОСЛІДЖЕНЬ У ВІТЧИЗНЯНОМУ ПОЛІТОЛОГІЧНОМУ ДИСКУРСІ
}

\author{
I.Ю. Свистун \\ Харківський національний педагогічний університет імені Г.С. Сковороди
}

У статті наведено особливості впливу громадських об'єднань на внутрішню політику держави. Зазначено, що громадські об'єднання за умов розвитку українського суспільства перетворилися на один із провідних чинників сучасного державотворення (комплексного довготривалого прочесу побудови демократичних структур та інститутів). Обгрунтовано законодавчу базу створення та функиіонування громадських об'єднань. Автором наведено основні функиії, щзо покликані виконувати громадські об'єднання. Також у статті автором розглянуто можливі форми здійснення взаємодіі між органами державної влади $i$ громадськими об'єднаннями та специфіку нормативного-правового забезпечення иього прочесу. На сучасному етапі розвитку суспільства громадські об'єднання виступають активними учасниками державотворчого прочесу. Автором статті пропонується визначати проблемне поле громадських об'єднань з позичій: уточнення категоріального апарату дослідження; розробки нормативно-правових засад їх виникнення та діяльності; виокремлення різних форм та типів їх існування; обгрунтування їх функціонального потенціалу.

Ключові слова: громадські об'єднання, державотворення, політичні прочеси, державна влада, внутрішня політика.

\section{ОБЩЕСТВЕННЫЕ ОБЪЕДИНЕНИЯ КАК ФАКТОР ОБРАЗОВАНИЯ ГОСУДАРСТВА: ОПРЕДЕЛЕНИЯ ПРОБЛЕМНОГО ПОЛЯ ИССЛЕДОВАНИЙ В ОТЕЧЕСТВЕННОМ ПОЛИТИЧЕКОМ ДИСКУРСЕ}

\section{И.Ю. Свистун}

В статье приведены особенности влияния общественных объединений на внутреннюю политику государства. Отмечено, что общественные объединения в условиях развития украинского общества превратились в один из ведущих факторов современного государства (комплексного длительного процесса построения демократических структур и институтов). Обосновано законодательную базу создания и функционирования общественных объединений. Автором приведены основные функции, которые призваны выполнять общественные объединения. Также в статье автором рассмотрены возможные формы осуществления взаимодействия между органами государственной власти и общественными объединениями, а также специфику нормативно-правового обеспечения этого прочесса. Отмечено, что на данном этапе развития общества общественные объединения выступают активнылми участниками государственного прочесса. Автором статьи предлагается определить проблемное поле общественных объединений $c$ позищий: уточнения категориального аппарата 
исследования; разработки нормативно-правовых основ их возникновения и деятельности; выделения различных форм и типов их существования; обоснования их функционального потенцииала.

Ключевые слова: общественные объединения, государство, политические процессы, государственная власть, внутренняя политика.

\section{PUBLIC ASSOCIATIONS AS A FACTOR IN THE FORMATION OF THE STATE: DETERMENING THE PROBLEM FIELD OF RECEARCH IN THE DOMESTIC POLITICAL DISCOURSE}

\section{Svystun}

The article presents the features of the influence of public associations on the internal policy of the state. It is noted that public associations in the conditions of development of Ukrainian society have become one of the leading factors of the modern state (a long complex process of building democratic structures and institutions). The legal basis for the establishing and functioning of public associations is well founded. The author describes the main functions that public associations are called upon to perform.

Also the author examines the possible forms of interaction between government authorities and public associations, as well as the specificity of the regulatory services for this process. It is noted that at this stage in the development of society, public associations are active participants in the government processes. The author of the article proposes to identify the problem field of public associations from the positions of: clarification of the categorical research of the study; the development of regulatory services for their occurrence and activity; the selection of various forms and types of their existence; justification of their functional capacity.

The development of an effective mechanism seems to be the most promising areas for further research in this sector of political science discourse (on the one hand, from the standpoint of the regulatory field, and on the other, the space for the development of civil society) of interactions of public associations with government bodies (all levels - from local to republican). policy.

Key words: public associations, state, policy processes, governmental authority, internal

Постановка проблеми: Сьогодні громадські об'єднання перетворилися на активних учасників політичних процесів, що відбуваються в країні. За безпосередньої участі громадськості відбувається вирішення низки питань державної ваги, а їх безпосередній вплив на формування і реалізацію державної політики стає все більш відчутним в умовах політичних та соціальних трансформацій, що сьогодні відбуваються в нашій країні. Зрозуміло, що за таких обставин у центр уваги вітчизняних науковців переміщуються саме проблеми виникнення та ефективної діяльності цих активних суб’єктів демократичних перетворень. 
Аналіз актуальних досліджень. Теоретичне визначення феномену громадських об'єднань в структурі політичної системи сучасної демократичної держави, як свідчать сучасні дослідження, носить міждисциплінарний та комплексний характер. Це соціальне явище досліджується політологами, соціологами, представниками юриспруденції та інших галузевих наук.

Дана проблематика є предметом дослідження українських політологів В. Баркова, С. Бистрицького, В. Кравчука, О. Палій, Ж. Пустовіт та інших.

Найбільш грунтовно тема правового статусу об'єднань громадян в Україні вивчається В. Авер'яновим, Н. Гаєвою, Т. Слінько, В. Погорілком, Ж. Пустовіт.

Мета статті полягає у визначенні проблемного поля дослідження громадських об'єднань як чинника державотворення у контексті аналізу сучасного українського політологічного дискурсу.

Виклад основного матеріалу. Демократична трансформація українського суспільства неможлива без спільних зусиль активних громадян, об'єднаних у громадські організації, які посилюють позиції громадянських ініціатив, висвітлюють актуальні соціальні, економічні, політичні проблеми, a їх діяльність наповнена змістом 3 урахуванням потреб реалізації внутрішньої політики держави. Громадські об’єднання виступають інструментом виявлення проблем i потреб громадян, а також засобом їх вирішення, важливим інструментом контролю 3 боку громадянського суспільства за діяльністю органів державної влади. У сучасному українському політологічному дискурсі існує досить багато різних визначень цього соціально-політичного феномену, але у вітчизняній літературі поняття «громадські об'єднання» найчастіше розуміють як добровільні формування громадян, створені у результаті їх вільного волевиявлення 3 метою вираження колективних інтересів i вирішення громадських питань та проблем (Законодавство України, 2018). Головними ознаками таких 
організацій є недержавність і неприбутковість. Ці дві властивості беруться як критерій для розмежування з іншими можливими об'єднаннями громадян.

Таким чином, прийнято вважати, що є три основні типи організацій в сучасному суспільстві: державні (органи влади, управління і т. ін.), прибуткові (фірми, підприємства) та усі інші недержавні й неприбуткові об’єднання громадян.

Аналіз наукових праць вітчизняних дослідників дає змогу стверджувати, що результатом багатьох років будівництва громадянського суспільства України спостерігається позитивна динаміка щодо створення та діяльності громадських об'єднань, збільшується кількість громадських об’єднань, зростає їхній вплив.

Діяльність громадських об'єднань грунтується на законодавчій базі. Правові засади створення i функціонування громадських об'єднань визначено Конституцією України, ст. 36 проголошує: «Громадяни України мають право на свободу об'єднання у політичні партії та громадські організації для здійснення і захисту своїх прав і свобод та задоволення політичних, економічних, соціальних, культурних та інших інтересів, за винятком обмежень, встановлених законом в інтересах національної безпеки та громадського порядку, охорони здоров'я населення або захисту прав i свобод інших людей. Громадяни мають право на участь у професійних спілках з метою захисту своїх трудових і соціально-економічних прав та інтересів. Професійні спілки є громадськими організаціями, що об’єднують громадян, пов'язаних спільними інтересами за родом їх професійної діяльності.

Проаналізувавши нормативно-правову базу діяльності громадських об’єднань в Україні, можна зазначити, що у відповідних законах та актах визначено та закріплено нормативно-правові засади їх утворення i функціонування, так:

- у статті 36 Конституції України - принцип рівності всіх об'єднань громадян перед законами; 
-у статті 37 Конституції України - виключно судовий порядок заборони діяльності об'єднань громадян;

- у статті 3 Закону України «Про громадські об’єднання» № 4572-VI від 22 березня 2012 р. - принципи діяльності: добровільності; самоврядності; вільного вибору території діяльності; рівності перед законом; відсутності майнового інтересу їх членів (учасників); прозорості, відкритості та публічності.

Громадські об’єднання досліджуються 3 боку вітчизняних представників політичної науки із позиції їх можливої типологізації / класифікації.

Класифікація об’єднань громадян в науковій літературі здійснюється за багатьма критеріями, найвідомішими серед яких є:

за рівнем політизованості або за місцем у політичній системі (політичні партії, суспільно-політичні організації, громадські організації);

за рівнем комерціалізації (некомерційні і неприбуткові організації, благодійні фонди);

за характером організованості (партії, рухи, організації);

за місцем у ієрархічній структурі (місцеві, регіональні або загальнодержавні організації, первинні організації або їх об’єднання, асоціації);

за напрямами діяльності, сферами інтересів (професійні, демографічні, творчі, спортивні, культурно-просвітницькі, науково-технічні тощо).

За рівнем стабільності такі, що постійно діють або тимчасові.

Разом $з$ цим, окремими фахівцями пропонується дещо інша типологія громадських об'єднань, а саме:

за завданнями діяльності (політичні, професійні, наукові, творчі та інші організаціi);

за типом членства (лише індивідуальне членство: партія, профспілка; лише колективне членство: асоціації міст і підприємств; змішане членство: наукове товариство без членства: суспільні рухи та ін.); 
за суспільною роллю (масові організації, що орієнтовані на справи всього суспільства і такі, що дбають переважно про потреби та інтереси своїх за галузями діяльності).

Крім того, Л. Лойко (2005, с. 51-60) досить детально розподіляє громадські об'єднання за спрямованістю на такі групи:

професійні (профспілки, асоціація фермерів тощо);

економічні (об’єднання підприємців, банкірів, роботодавців тощо);

соціально-демографічні (молодіжні, ветеранські, жіночі);

конфесійні (церкви, релігійні общини, об’єднання мирян);

культурологічні та просвітницькі;

творчі (об’єднання артистів, письменників, художників);

спортивно-туристські та оздоровчі;

наукові та науково-технічні;

оборонні;

національно-культурні;

екологічні.

Наукові публікації, присвячені розгляду проблем громадських об’єднань, також містять дослідження щодо визначення функціонального потенціалу останніх.

У вітчизняному політологічному дискурсі стверджується, що громадські об'єднання покликані виконувати, насамперед, функції:

- налагодження партнерського діалогу між громадськістю та органами державної влади;

- усунення будь-яких непорозумінь та перешкод для забезпечення соціальної злагоди, сприятливої атмосфери для розбудови вільного, неупередженого ставлення щодо влади, громадянського суспільства.

Слід зазначити, що при визначенні головних функцій діяльності цих соціально-політичних суб'єктів, дослідники справедливо одночасно звертають увагу на два моменти: $з$ одного боку, на визначення можливих 
форм здійснення взаємодії між органами влади і об'єднаннями громадян, а 3 іншого - обгрунтування нормативно-правових засад цієї діяльності.

Щодо першого моменту, то конструктивним визнається пропозиція Н. Ротар виокремлювати чотири основні варіанти діалогу між владою і об’єднаннями громадян. Перший передбачає використання владою традиційної стратегії взаємодії з громадянами згори - вниз, яка грунтується на наданні останнім мінімуму інформації про перебіг процесу ухвалення політичних рішень та повністю заперечує їх суб’єктність в процесі формування їх політичного порядку денного. Фактично цей тип діалогу є монологом влади, який претендує винятково на схвальну оцінку з боку громадян. Другий варіант діалогу - взаємодія, обмежена згори - є стратегією обмеженого діалогу, коли влада погоджується приймати пропозиції від громадян, проте не реагує на них. Третій варіант передбачає відкритий діалог між владою і громадянами. Проте остаточний вибір пріоритетів залишається за владою, оскільки вона обирає стратегію взаємодії. Четвертий варіант діалогу, який відповідає принципам функціонування демократії участі, формується на основі спільного володіння інформацією, тому пересічні громадяни є рівними 3 владою суб'єктами політичного процесу, a їх пропозиції мають таку ж вагу, як і пропозиції влади. Зауважимо, що тільки останній варіант діалогу між владою та громадянами передбачає і рівні права щодо контролю за реалізацією спільно ухвалених політичних рішень (Ротар, 2007). В Україні у повному обсязі реалізовано перший варіант діалогу i робляться спроби засвоїти другий та третій варіанти. Однак нестабільний характер взаємодії між основними гілками влади, намагання політичної еліти тримати все під власним контролем не дозволяє їй обирати більш розкуті варіанти політичних стратегій у взаємодії 3 громадянами. Наслідок: поширення серед громадян тенденції до абсентеїзму та поглиблення кризи довіри до демократичних інститутів.

Щодо другого моменту, то регулювання функціональної діяльності органів державної влади і громадських організацій та об'єднань 
пропонується вибудовувати на основі партнерства, взаємодії, за відсутності втручання до внутрішньої діяльності кожного із суб’єктів цієї взаємодії. Тобто, їх функціональна діяльність має зводиться на принципі не супідрядності (в такому випадку органи державної влади не втручаються в роботу громадських організацій та об’єднань, а громадські організації та об’єднання - в роботу органів державної влади). Даний принцип був законодавчо закріплений в Законі України «Про громадські об’єднання» провідна роль у питаннях взаємодії між органами державної влади та громадськими організаціями і об’єднаннями належить державним органам, адже саме держава, має верховенство влади, забезпечує громадським організаціям і об’єднанням правову основу їх створення і функціонування. Абсолютно всі громадські організації і об’єднання діють на підставі єдиної законності. Таким чином, органи державної влади не повинні втручатися у внутрішню діяльність громадських організацій i об’єднань, а мають виступати ініціатором їх співпраці та конструктивної взаємодії, брати на себе головуючу роль у питанні координації взаємовідносин між собою (Ротар, 2007 c. $75-92)$.

Слід також зазначити, що у контексті дослідження двох вищезазначених моментів громадські об'єднання виступають не лише ефективним інструментом взаємодії й конструктивного діалогу між громадськістю та органами державної влади і місцевого самоврядування, вони стали активними учасниками політичних процесів, активно впливають на формування й реалізацію державної внутрішньої політики країни, мають вагомий вплив на процес державотворення. Тобто, можна стверджувати, що громадські об’єднання за умов розвитку українського суспільства перетворилися на один із провідних чинників сучасного державотворення (комплексного довготривалого процесу побудови демократичних структур та інститутів).

Це твердження також базується й на результатах щодо обгрунтування основних напрямів впливу громадських об'єднань на органи державної влади 
(всіх рівнів), які презентовані у відповідних дослідженнях вітчизняних фахівців. Згідно до цих результатів:

1) громадські об’єднання беруть участь у формуванні корпусу депутатів органів державної влади;

2) представники громадських об’єднань входять до складу певних державних колегіальних органів як їх повноправні члени з ухвалювальним голосом;

3) керівні органи певних громадських організацій можуть бути суб'єктами законодавчої ініціативи;

4) у ряді випадків державні органи приймають рішення лише спільно або за погодженням з громадськими об’єднаннями;

5) окремі громадські організації (за умов дозволу держави) 3 певних питань цілком самостійно приймають формально обов’язкові (юридичні) рішення нормативного або індивідуального характеру;

6) певним громадським об’єднанням дозволено контролювати діяльність деяких державних організацій;

7) за порушення деяких юридичних норм державою передбачено можливість застосування конкретних заходів з боку громадських об’єднань (Кравчук, 2007, с. 48-53).

Висновки і перспективи подальших досліджень. Спираючись на результати цього дослідження, можемо зазначити, що у сучасному політологічному дискурсі громадські об'єднання:

по-перше, постають гарантами непорушності, реалізації та захисту особистих прав людини і громадянина;

по-друге, є засобом самоорганізації членів суспільства та реалізації ними інтересів;

по-третє, виступають ефективним інститутом демократичного контролю за функціонуванням органів державної влади і ступенем втручання держави у суспільні відносини; 
по-четверте, дають громадянам можливість безпосередньо впливати на процес прийняття важливих для суспільства рішень.

Тобто, серед вітчизняних науковців та політиків формується стійка тенденція до розгляду сучасних громадських об'єднань як чинника державотворення (реального інструменту, за допомогою якого можна сформувати міцну демократичну державу i реформувати у напряму подальшої демократизації різні суспільні структури та інституції).

За цих обставин проблемне поле громадських об’єднань пропонується визначати 3 позицій: уточнення категоріального апарату дослідження; розробки нормативно-правових засад їх виникнення та діяльності; виокремлення різних форм та типів їх існування; обгрунтування їх функціонального потенціалу та ін.

Найбільше перспективними напрямами щодо подальших досліджень у цьому секторі політологічного дискурсу вбачається розробка дієвого механізму (з одного боку, з позиції нормативно-правового поля, а 3 іншого простору розвитку громадянського суспільства) взаємодії громадських об'єднань з органами державної влади (всіх рівнів - від місцевого до республіканського).

\section{ЛIТЕРАТУРА}

1. Законодавство України, 2018. Закон Украӥни «Про громадські об'єднання» від 22.03.2012 p. № 4572-VI. [online] Доступно: http://zakon1.rada.gov.ua/laws/show/457217 [Дата звернення 20 січня 2019].

2. Кравчук, В., 2007. Деякі підходи до класифікації громадських організацій в Україні. Вибори та демократія, 1(11), с. 48-53.

3. Лойко, Л., 2005. Типологічне позиціювання національних організацій в інституціональній структурі громадянського суспільства. Політичний менеджмент, 5, c. 51-60.

4. Ротар, Н., 2007. Діалогові форми політичної участі: передумови та перспективи становлення в Україні. Політичний менеджмент, 1, с. 75-92.

\section{Інформація про автора}

Свистун Ірина Юріївна - аспірант кафедри політології, соціології і культурології Харківського національного педагогічного університету імені Г.С. Сковороди; e-mail: irinasvistun25@gmail.com; ORCID: http://orcid.org/0000-0002-7851-4605.

Стаття надійшла до редакції: 22.01. 2019 р. $\quad$ Прийнята до друку: 05.02.2019 р. 